\title{
II. Dünya Savaşı'nda Çizgi Filmlerin Mihver Devletleri Tarafından Karşı Propaganda Amaçlı Kullanımı
}

\author{
Mehmet Ali Gazi* \\ Caner Çak1*
}

\section{Özet}

Çalışmada II. Dünya Savaşı'nda üç büyük Mihver Devleti Almanya, İtalya ve Japonya tarafindan çizgi filmlerin propaganda amaçl kullanımı ortaya konulmaya çalışılmıştır. Bu amaçla çalışmada, 1940 Almanya yapımı Der Störenfried (Oyunbozan), 1941 Italyan yapımı Il Dottor Churkill (Doktor Churkill) ve 1943 Japonya yapımı Momotarō no Umiwashi (Momotaro'nun Deniz Kartalları) çizgi filmleri nitel araştırma yöntemleri içerisinde yer alan göstergebilimsel analiz yöntemi kullanılarak incelemiştir. Çalışmada çizgi filmler, İsviçreli Dil Bilimci Ferdinand de Saussure'ün göstergebilim anlayışı çerçevesinde analiz edilmiştir. Elde edilen bulgular ışı̆̆ında, Mihver Devletleri'nce çekilen propaganda amaçh çizgi filmlerde Müttefik Devletleri'nin dünyayı işgal etmeye çalışan düşmanlar olarak aktarıldığı ve bu yolla kamuoyunda Mihver Devletleri'ne karşı nefret söylemi inşa edilmeye çalışıldığı görülmüştür. Diğer yandan çizgi filmlerde Mihver Devletleri'nin dünyayı işgal etmeye çalışan Müttefik Devletleri'ne karşı dünyanın huzur ve barışı için büyük bir mücadele başlattığıına dair algı oluşturulduğu ortaya çıkarılmıştır. Böylece Mihver Devtletleri'nin çizgi filmler üzerinden savaşı meşrulaştırmaya çalıştı̆̆ı ve Müttefik Devletleri'ne karşı kamuoyundan destek bulmaya çalıştıkları sonucuna ulaşılmıştır.

Anahtar Kelimeler: Çizgi Film, Propaganda, Mihver Devletleri, 2. Dünya Savaşı, Göstergebilim

ORCID ID : https:/ / orcid.org/ 0000-0002-9239-4187 - 0000-0002-1523-4649

E-mail :mehmetaligazi@hotmail.com - caner.caki@inonu.edu.tr

DOI: 10.31122/Sinefilozofi.542931

Geliş Tarihi - Recieved: 21.03.2019

Kabul Tarihi - Accepted: 16.10.2019 


\title{
The Use Of Cartoon Films For Counter Propaganda By The Axis Powers In World War II
}

\author{
Mehmet Ali Gazi* \\ Caner Çak1*
}

\begin{abstract}
In this study, the use of cartoons for propaganda purposes by the three big Axis Powers (Germany, Italy and Japan) in World War II was tried to be revealed.For this purpose, in the study, 1940 German made Der Störenfried, 1941 Italian made Il Dottor Churkill (Doctor Churkill) and 1943 Japan made cartoons Momotarō no Umiwashi (Momotaro's Sea Eagles) were analyzed using the semiotics analysis method in qualitative research methods. Cartoons in the study were analyzed within the framework of the semiotics concept Swiss Language Scientist Ferdinand de Saussure. In the light of the findings, it was seen that the Allied States were presented as enemies trying to invade the world in the propaganda films made by the Axis Powers and in this way, the public opinion was tried to build hate speech against the Axis Powers. On the other hand, it was revealed in the cartoons that the Axis Powers started a great struggle for peace of the world against the Allied Powers which tried to occupy the world. Thus, it was concluded that the Axis Powers tried to legitimize the war through cartoons and tried to find public support against the Allied Powers.
\end{abstract}

Key Words: Cartoon, Propaganda, Axis Powers, World War II, Semiotic

ORCID ID : https:/ / orcid.org/ 0000-0002-9239-4187 - 0000-0002-1523-4649

E-mail : mehmetaligazi@hotmail.com - caner.caki@inonu.edu.tr

DOI: 10.31122/Sinefilozofi.542931

Geliş Tarihi - Recieved: 21.03.2019

Kabul Tarihi - Accepted: 16.10.2019 


\section{Giriş}

2. Dünya Savaşı'nda Müttefik Devletleri ${ }^{1}$ kamuoyundan destek alabilmek için Mihver Devletleri'ne karşı çizgi filmleri propaganda amaçlı yoğun bir şekilde kullanmıştır. Özellikle ABD'nin Walt Disney firması Mihver Devletleri' ne yönelik nefret söylemi oluşturmak amacıyla pek çok propaganda çizgi filmi üretmiştir. Üretilen çizgi filmler, ABD'de büyük izleyici kitlesine ulaşmayı başarmıştır ve ABD yönetimince de finanse edilmiştir. Bu aşamada, çizgi filmlerin propagandadaki etkisinin farkına varan Almanya, İtalya ve Japonya'nın önderliğindeki Mihver Devletleri, Müttefik Devletleri'nce üretilen çizgi filmlere karşı propaganda amacıyla yeni çizgi filmler üretmiştir. Mihver Devletleri' nin ürettiği çizgi filmlerde, Müttefik Devletleri ağır bir dille eleştirilirken, savaş esnasında yapılanlar ile ilgili meşruiyetin de sağlanması amaçlanmıştır. Buna karşın Mihver Devletleri'nce üretilen çizgi filmler, gerek ulaştığ1 kitlenin hedeflenen düzeyde olmaması, gerekse yapımdaki düşük kalite nedeniyle Müttefik Devletleri' nin çizgi filmleriyle rekabet edecek boyuta ulaşamamıştır.

Müttefik Devletleri'nin çizgi filmlerine yönelik, Mihver Devletleri'nce üretilen çizgi filmler, savaş döneminde karşı propaganda amaçlı üretilen ilk çizgi filmler olması açısından büyük önem taşımaktadır. Diğer yandan çizgi filmler, Mihver Devletleri'nin 2. Dünya Savaşı'ndaki propaganda faaliyetlerine de ş̧ık tutmaktadır.

Çizgi filmlerin İkinci Dünya Savaşı'nda propaganda amaçlı kullanımlarıyla ilgili önemli çalışmalar yapıldığı görülmektedir. Bunlar içerisinde; Raiti (2007: 153), 1940'lı yılların Disney animasyon propagandasının değişimini; Delporte (2001: 367), İkinci Dünya Savaşı'nda Vichy Fransası'nda propaganda amaçlı üretilen çizgi filmi; Shull ve Wilt (2014:12), ABD özelinde İkinci Dünya Savaşı dönemindeki propaganda çizgi filmlerini; Jones (1988 729), ABD hükümetinin gelir elde etmek amacıyla çizgi filmleri propaganda amaçlı kullanımını incelediği çalışmalar ön plana çıkmaktadır.

Çalışmada kapsamında ise Üçlü Mihver Paktı'nın üyeleri Nazi Almanyası, İtalya ve Japonya'nın çizgi filmlerinden seçilen birer örnek üzerinden Mihver Devletleri'nin İkinci Dünya Savaşı'nda propaganda faaliyetlerine 1şık tutulmaya çalışılmıştır.

\section{İkinci Dünya Savaşı'nda Müttefik Devletleri'ne Karşı Olarak Gerçekleştirilen Mihver Devletleri'nin Propaganda Faaliyetleri}

Mihver Devletleri, 2. Dünya Savaşı'nda 1940-1945 yılları arasında Müttefik Devletleri'ne karşı savaşan ülkeleri ifade etmek için kullanılan bir kavramdır. Mihver Devletleri'nin ilk adımı 1936 yılının Ekim ayında Almanya ve İtalya arasında imzalanan anlaşma ile oluştu. Daha sonra Almanya ve Japonya'nın aynı yılın Kasım ayında imzaladıkları Anti-Komintern Pakt ile birlikte Mihver Devletleri'nin ana yapısı şekillendi. Son olarak, Nazi Almanyası, İtalya ve Japonya arasında 27 Eylül 1940 yılında imzalanan Tripartite Anlaşması (Üç Güç Paktı) ile Mihver Devletleri resmi olarak meydana gelmiş oldu (Eberle ve Uhl, 2017: 584). Mihver Devletleri'ne daha sonra Macaristan, Bulgaristan ve Romanya'da katılmıştı. Mihver Devletleri, İkinci Dünya Savaşı sırasında, Müttefik Devletleri'ne karşı etkili bir propaganda faaliyeti yürütmeye çalışmıştır.

Propaganda kavramı, kitle iletişim araçları vasıtasıyla kitlelerin bir ideoloji, fikir veya düşünce üzerinde ikna edilmesi çabasını ifade etmektedir. Savaş zamanında propaganda, rakiplerin zayıf noktalarını bularak onları kitleler nezdinde zayıf ve haksız duruma düşürmek için kullanılmaktadır (Domenach, 2003: 80-81). 2. Dünya Savaşı'nda da Mihver Devletleri,

1 İkinci Dünya Savaşı sırasında, Almanya, İtalya ve Japonya'nın liderlik ettiği Mihver Devletleri'ne karşı Amerika Birleşik Devletleri, Sovyetler Birliği, İngilitere ve müttefiklerinden oluşan blok. 
Müttefik Devletleri'ne üstün gelebilmek için yoğun bir propaganda savaşı içine girmişti.

Nazi Almanyası lideri Adolf Hitler, kitlelerin istenilen yönde hareket etmesinde propagandanın büyük rol oynadığını ileri sürmekteydi (Hitler, 2004: 151). Nazi Almanyası'nda propaganda faaliyetlerinin yürütülmesi amacıyla Dr. Joseph Goebbels önderliğinde Halkı Aydınlatma ve Propaganda Bakanlığı kuruldu. Bakanlığın temel amacı Nazizm ideolojisini Alman toplumunun her kesimine kabul ettirmek, Almanya' da Nazi rejimine karşı oluşabilecek her türlü karşı propagandayı da ortadan kaldırmaktı. 2. Dünya Savaşı'nda Nazi propagandası, Müttefik Devletleri' nin Yahudiler ile iş birliği içerisinde hareket ettiği üzerinde konumlandırıldı (Yücel, 2017: 156). Naziler, ABD Başkanı Franklin D. Roosevelt, İngiltere Başkanı Winston Churchill ve Sovyetler Birliği lideri Joseph Stalin'in Yahudilerin tahakkümü altına girdiğini ve onların emirleri altında dünyayı büyük bir felakete sürüklediğini iddia eden propaganda faaliyeti yürüttü (Goebbels, 2016: 24-25). Böylece Nazizm ideolojisindeki Antisemitizm (Yahudi Düşmanlığı), Müttefik Devletleri'ne karşı oluşturulan nefret söyleminde ön plana çıkarıldı.

Naziler, 2. Dünya Savaşı başladığında Almanya' da yaygın bir radyo ağına sahipti. Almanların yalnızca Alman radyo kanallarını dinlemesine izin verilmekteydi. Müttefik Devletleri'nin radyo yayınlarını dinlemek yasaklanmıştı (Kuruoğlu, 2006: 21). Özellikle, 1943 yılında Nazilerin cephelerde yenilgi almaya başladığı, Stalingrad, Kursk, Sicilya Muharebeleri'nden sonra bu yasak daha sıkı bir şekilde uygulanmaya başlanmıştı. Naziler, ABD' de Hollwoody tarafından Charlie Chaplin'in baş rolünü oynadığı, Hitler ve Mussolini'yi mizahi yönden eleştiren1940 yapımıBüyük Diktatör gibi propaganda filmlerine karşı Müttefik Devletleri'ni ağır şekilde eleştiren propaganda amaçlı filmler çekmekteydi (Zorlu vd., 2017: 90). Naziler savaşın son günlerine kadar Alman halkını Müttefik Devletleri'ne karşı direnişe çă̆ıran Veit Harlan yönetmenliğindeki Kolberg (1945) gibi propaganda filmlerini çekmeye devam etti. Diğer yandan, Naziler yazılı basında da Müttefik Devletleri'ne karşı yoğun bir şekilde karşı propaganda yürütmekteydi. Nazilerin parti gazeteleri Völkischer Beobachter ve Der Angriff Müttefik Devletleri'ni 2. Dünya Savaşı'nın yegane sorumlusu olarak göstermekteydi. Lustige Blätter gibi mizah dergileri de Müttefikleri gülünç duruma düşürerek Alman halkı gözünde itibarsızlaştırmaktaydı (Kallis, 2005: 120). Müttefik Devletleri'ne karşı Hitler'in karizmatik liderliği bir kurtarıcı olarak Alman halkına sunulmaktaydı. Aynı zamanda Sovyetler Birliği'nde de karizmatik lider olarak inşa edilen Stalin' in otoritesini sarsan propaganda faaliyetlerine yer verilmekteydi (Gazi vd., 2018: 29).

İtalya, Büyük Roma İmparatorluğu'nu tekrar kurma planları yapmaktaydı. Bu yüzden İtalyan lider Benito Mussolini, İtalyan propagandasında kitleler gözünde eski Roma imparatorlarını hatırlatacak şekilde kült lider olarak inşa edilmekteydi (Domenach, 2003: 90). Müttefik Devletleri, İtalya'ya karşı yürütülen propaganda faaliyetlerinde doğrudan İtalyan lideri Mussolini'yi hedef almakta ve onu tüm savaşta yaşanan olumsuzlukların sorumlusu olarak göstermekteydi (Öymen, 2014: 226). İtalyan propagandasının, Alman propagandasi ile en benzer yönü Sovyetler Birliği ve Komünizm ideolojisi aleyhtarı söylemlere sıklıkla yer vermesiydi. İtalya, Müttefik Devletleri'nin İtalya üzerinde gerçekleştirdiği hava bombardımanını, Müttefik Devletleri'ne karşı nefret söylemi inşasında kullanmaktaydı (Çankaya, 2008: 32). İtalyan propagandasında, Müttefik Devletleri, İtalya'yı yıkıma sürükleyen ve İtalya'nın tarihi eserlerini yağmalayan askerler olarak sunulmaktaydı. 1943 yılında İtalya, Nazi Almanyası tarafından işgal edilip, Nazilerin desteğinde Faşist İtalyan Sosyal Cumhuriyeti kurulduğunda, İtalyan propagandası tamamen Nazilerin denetimine girmişti. Bu süreçte İtalyan propagandasi, Nazileri dost ve müttefik olarak daha vurgulu bir şekilde göstermeye, Müttefik Devletleri'ni de tıpkı Almanya'da olduğu gibi Yahudilerin tahakkümü altında hareket eden ve İtalya'nın yok olması için çalışan ülkeler olarak yansıtmıştı. 
Japonya,2.DünyaSavaşı' nınsonaylarınakadarSovyetlerBirliğgi' nekarşısavaşagirmemişti. Bu yüzden müttefikleri Almanya ve İtalya'dan farklı olarak propaganda faaliyetlerini, ABD, İngiltere ve Avustralya üzerine yoğunlaştırmıştı. Japon propagandası, askerlerini Japon İmparatorluğu'nu Müttefik Devletleri'ne karşı korumak için savaştırdığına ikna etmekteydi. Japon propagandası Japon askerleri üzerinde önemli bir etki bırakmayı başarmıştı. Örneğin, Müttefik Devletleri'ne karşı nefret söylemi ile cepheye gönderilen Japon pilotlar, Müttefik Donanması'na yönelik kamikaze adı verilen ihtihar saldırıları gerçekleştirmekteydi (Jowett ve O'donnell, 2014: 59). 2. Dünya Savaşı'nda Japonya' nın tüm propaganda faaliyetleri Başbakan General Hideki Tojo tarafından görevlendirilen askeri yönetim tarafından planlanmaktaydı. Japonya, propaganda çalışmalarını Eğitim Bakanlığı bünyesinde oluşturulan Düşünce İdaresi Bürosu adında bir merkezden yürütmekteydi. Japonya, propaganda faaliyetlerinde genel olarak ABD'yi hedef almaktaydı. ABD'ye yönelik yürütülen propaganda faaliyetlerinde, emperyalist güçlerin Japonya' yı yok etmeyi planladıkları vurgulanarak, Japon halkı gözünde ABD’ye yönelik nefret söylemi inşa edilmeye çalışılmaktaydı (Akarcalı, 2002: 162-163).

\section{İkinci Dünya Savaşı'nda Mihver Devletleri'nin Çizgi Filmleri Propaganda Amaçlı Kullanmasi}

Çizgi filmler, İkinci Dünya Savaşı'nda Müttefik Devletleri tarafından propaganda amaçlı etkili bir şekilde kullanılmıştır. Bu dönemde çizgi filmlerden, güldürü öğesi olmasının yanında hükümetler tarafından kitleleri belirli bir konuda ikna etmek, kamuoyunun desteğini almak ve düşman ülkelere karşı nefret oluşturmak amacıyla yararlanılmıştır. Özellikle ABD tarafından, Amerikan halkını Mihver Devletleri'ne karşı savaşa ikna edebilmek amacıyla çizgi filmler üretilmiştir. Bu süreçte $\mathrm{ABD}^{\prime}$ de bulunan Walt Disney medya şirketi, Amerikan propagandasına büyük hizmetlerde bulunmuştur. Savaşla birlikte Walt Disney karakterleri, birbirlerine karşı mücade etmeyi bırakmış, bunun yerine Mihver Devletleri'ne karşı mücade etmeye başlamıştır. Çizgi filmlerde temel konu Amerika'yı ve insanlığı kötü olarak gösterilen Mihver güçlerine karşı savunmak olmuştur.

Müttefik Devletleri'nin aksine Mihver Devletleri, çizgi filmlere propaganda amaçlı yeterli desteği vermemiştir. Nazi Almanyası, propaganda amaçlı daha çok uzun metrajlı sinema filmleri üzerinden kitleleri etkileme yolunu seçmiştir. Propaganda amaçlı hazırlanan sinırlı sayıda çizgi film ise sinema filmlerine göre oldukça amatörce, düşük kalitede ve uzun soluklı olmayacak şekilde hazırlanmıştır. Naziler tarafından hazırlananlar daha çok haber aralarında kitleleri neşelendirmek amacıyla kullanılan kısa çizgi filmlerden oluşmuştur. Naziler, propaganda mesajlarını çizgi filmler üzerinden vermek yerine belirli aralıklarla yayınlanan Wochenschau adlı haber bültenleri ile vermeyi seçmiştir (Winkel, 2004: 20-21). Diğer yandan propaganda mesajlarının mizah öğesi ile birlikte verilmesi istendiğinde de yine sinema filmleri devreye girmiştir.

Nazi Almanyası'nda çizgi filmlerin etkili bir şekilde kullanılamamasının altında pek çok farklı neden bulunmaktadır. Bunlardan biri Nazilerin, Almanya' da iktidara gelmesinden sonra Alman film yapımcılarından bir kısmının ülkeyi terk etmesidir. Naziler, film yapımcılarının bir kısmının Almanya' yı terk etmesinden sonra film sektörü üzerinde doğrudan müdahalede bulunmuştur. Bu süreçte Naziler, film sektöründe önemli bir etkiye sahip olmuştur (Schütz, 1995: 140). Nazilerin denemitinde gelişen Alman filmlerinde ise çizgi filmin propaganda etkisi yeterince ciddiye alınmamış ve daha çok sinema filmleri üzerine odaklanılmıştır. Örneğin, Naziler büyük bir bütçe ayırarak Alman yönetmen Leni Riefenstahl'e İrade'nin Zaferi (Triumph des Willens) adlı propaganda filmini hazırlatmıştır (Loiperdinger, 1993: 40). Bu süreç, Nazi Almanyası' nın teslim olacağı 1945 yılına kadar devam etmiştir. 
İtalya'da ise film sektöründe propaganda faaliyetleri etkili bir şekilde kullanılamamıştır. $\mathrm{Bu}$ açıdan propaganda boyutunda değerlendirildiğinde İtalya'daki çizgi filmler, Müttefik Devletleri tarafından çekilen çizgi filmler ile kıyaslandı̆̆ında oldukça yetersiz kalmıştır. Japonya'da film sektörü doğrudan askerlerin denetiminde bulunan hükümet tarafından kontrol edilmiştir. Bu dönemde Japonya'da hazırlanan en etkili iki propaganda çizgi filmi, Mitsuyo Seo yönetmenliğindeki 37 dakikalık Momotaro no Umiwashi (Momotaro'nun Deniz Kartalları) ve 74 dakikalık Momotaro Umi no Shimpei (Momotaro'nun Tanrılar-Kutsanmış Deniz Savaşçıları) olmuştur (Patten, 1996: 16).

\section{Yöntem}

\section{Çalışmanın Amacı}

2. Dünya Savaşı, propagandanın dünya tarihi içerisinde en etkili kullanıldığı dönemi oluşturmaktadır. Çalışma kapsamında 2. Dünya Savaşı'nda Mihver Devletleri tarafından üretilen çizgi filmler özelinde, çizgi filmlerin propaganda amaçlı nasıl ve ne yönde kullanıldığını açıklanmak çalışmanın temel amacını oluşturmaktadır. Elde edilen bulgular çerçevesinde, 2. Dünya Savaşı'nda Mihver Devletleri'nin propaganda faaliyetlerine de 1şık tutulması çalışmanın bir diğer amacını meydana getirmektedir.

Çalışma, 2. Dünya Savaşı'nda Mihver Devletleri'ne liderlik eden ve nüfus bakımından Mihver Devletleri'nin en kalabalık üç ülkesi olan Almanya, İtalya ve Japonya yapımı çizgi filmler üzerinden gerçekleştirilmiştir. Çalışma kapsamında incelenen Mihver Devletleri'ne ait çizgi filmler içerisinde, Müttefik Devletleri'ni hedef alması, Mihver Devletleri'ni yücelten mesajlara yer vermesi ve doğrudan Müttefik Devletleri ile Mihver Devletleri arasındaki mücadeleyi konu alması dolayısıyla çalışma, Almanya yapımı Der Störenfried (Oyunbozan, 1940, yönetmen Hans Held), İtalya yapımı Il Dottor Churkill (Doktor Churkill, 1941, yönetmen Liberio Pensuti) ve Japonya yapımı Momotarō no Umiwashi (Momotaro'nun Deniz Kartalları, 1943, yönetmen Mitsuyo Seo) adlı üç çizgi film üzerinden yürütülmüştür.

\section{Çalışmanın Önemi}

Çalışma, 2. Dünya Savaşı'nda Mihver Devletleri tarafından çizgi filmlerin propaganda amaçlı nasıl kullandığı hakkında bilgi vermesi ve çizgi filmlerde Müttefik Devletleri'nin nasıl sunulduğunu ortaya koyması bakımından önem taşımaktadır.

Çalışmada elde edilen bulgular, İkinci Dünya Savaşı'nda Mihver Devletleri'nin çizgi filmlere verdiği önemi ve çizgi filmlerin Mihver propagandasındaki rolünü ortaya koymaktadır. Başta Walt Disney olmak üzere Müttefik Devletleri tarafından hazırlanan propaganda çizgi filmlerine karşılık olarak, Mihver Devletleri'nin ne tür propaganda çizgi filmleri hazırladığ1 konusunda bilgi verilmesi hedeflenmektedir. Böylece çalışmada çizgi filmlerin yalnızca Müttefik Devletleri tarafından değil aynı zamanda Mihver Devletleri tarafından da etkili birer propaganda aracı olarak kullanıldığının ortaya konulmasına çalışılmaktadır.

\section{Çalışmanın Sınırlılıkları}

Çalışmanın yalnızca üç çizgi film özelinde yürütülmesi ve elde edilen bulgular ışığında 2. Dünya Savaşı'nda Mihver Devletleri'nin propaganda faaliyetleri hakkında genellemelerde bulunulması çalışmanın temel sınırlılığını oluşturmaktadır. 


\section{Çalışmanın Soruları}

Çalışma kapsamında şu sorular sorulmuştur;

-2. Dünya Savaşı'nda Mihver Devletleri çizgi filmlerde Müttefik Devletleri'ne yönelik hangi propoganda söylemini/söylemlerini inşa etmeye çalışmıştır?

-2. Dünya Savaşı'nda Mihver Devletleri çizgi filmlerde düşman olgusu oluştururken hangi öğeleri ön plana çıkarmaktadır?

\section{Çalışmanın Yöntemi}

Çalışma kapsamında çizgi filmler nitel araştırma yöntemleri içerisinde yer alan göstergebilimsel analiz yöntemi kullanılarak incelenmiştir. Çizgi filmler İsviçreli Dil Bilimci Ferdinand de Saussure' ün göstergebilim anlayışı 1şı̆̆ında analiz edilmiştir.

Göstergebilim, göstergeler yoluyla oluşan veya oluşturulmak istenen anlamları inceleyen bir bilim dalıdır (Rifat, 2013: 214). Göstergebilim, 20. yüzyılın başlarında İsviçreli Dil Bilimci Ferdinand de Saussure ve ABD'li Dil Bilimci Charles Sanders Peirce'in dil bilim üzerine yaptığı çalışmalar ile önem kazanmaya başlamıştır. Saussure'ün ölümünden sonra öğrencileri tarafından dil bilimi üzerine yaptığı çalışmalar Genel Dil Bilim Yazıları adı altında kitap haline getirilmiştir.

Göstergebilimin temelini oluşturan gösterge insanların zihinlerinde uyarıcı olarak görev görür ve uyardığı belleksel imge zihinde diğer bir uyarıcının imgesi ile bağlantı kurar. Göstergenin temel işlevi, bu ikinci imgenin zihinde canlanmasını sağlamaktır (Guiraud, 2016: 39). Saussure'ün göstergebilimsel çözümlemesi gösteren ve gösterilen olmak üzere iki düzlem üzerine temellenmektedir (Kalkan Kocabay, 2008: 16).

Gösteren, insanlar tarafından algılanan imgeyi ifade etmektedir; kağıt üzerinde bulunan işaretler, havadaki sesler gibi. Buna karşın gösterilen, gösterenin insan zihninde göndermede bulunduğu zihinsel kavramı oluşturur. Oluşan bu kavram, aynı kültür içerisinde bulunan insanlar için ortak anlamı ifade etmektedir (Fiske, 2017: 127). Örneğin, bir erkeğin sevgilisine gül verdiğini ele alalım. Gül, gösteren boyutta bir çiçeği ifade etmektedir. Buna karşın gösterilen açıdan erkeğin, sevdiği kıza olan sevgisinin bir sembolü haline gelebilmektedir. Saussure, göstergebilimi toplumsal nitelikli olarak görmektedir. Bu açıdan Saussure, dili, nesneler ve onların karşılığı olarak ifade edilen sözcükler arasındaki ilişkiyi toplumdaki uzlaşma temeli içerisinde değerlendirerek, dili toplumsal boyutuyla ele alır (Sı̆̆ırc1, 2016: 30-31). Saussre'e göre göstergebilim çok geniş bir alanı meşgul eden bir kavramdır. Bu açıdan, göstergebilime insanbilimi, ruhbilimi, toplumbilimi gibi farklı disiplinler katkı sağlamaktadır.

Diğer bir deyişle, göstergebilim kapsadığı alan bakımından insan bilimlerini derinden etkilemektedir (Tekinalp ve Uzun, 2013: 139).

Saussure' ün göstergebilime yapmış olduğu katkılar daha sonra Roland Barthes, Claude Lévi-Strauss gibi dil bilimcilerin çalışmalarının temelini oluşturmuştur (Tanyeri Mazıcı ve Çakı, 2018: 296). Bu çalışmanın konusu, Saussure'ün göstergebilime katkılarını ayrıntılı bir şekilde ortaya koymak değildir. Çalışmanın amacı Saussure'ün göstergebilimsel çözümleme yöntemi ile 2. Dünya Savaşı'nda Mihver Devletleri tarafından oluşturulan çizgi filmlerin propaganda amaçlı kullanımlarının analizini yapmaktır. 


\section{Analiz}

Çalışmanin bu bölümünde, Der Störenfried (Oyunbozan), Doktor Churkill (Doktor Churkill) ve Momotarō no Umizwashi (Momotaro'nun Deniz Kartalları)adlı çizgi filmlerin propaganda bağlamında göstergebilimsel analizi yapılmıştır.

\section{OyunbozanAdlı Çizgi Filmin Göstergebilimsel Analizi}

Der Störenfried (Oyunbozan), Hans Held yönetmenliğindeki 1940 yapımı Alman propaganda çizgi filmidir. Çizgi film, bir tavşan ailesini konu edinmektedir. Bir gün bir tilki yavru tavşanları kaçırmaktadır (Resim 1). Bunun üzerine baba tavşan tilkinin peşine düşmektedir. Fakat tilkinin çocukları kaçırmasına mani olamamaktadır. Anne tavşan, baba tavşana hesap sormakta ve ne pahasına olursa olsun çocuklarını tilkinin elinde kurtarmasını istemektedir (Resim 2). Baba tavşan da, köpeklerden oluşan askerlerin yanına gitmektedir (Resim 3). Askerler, eşek arıları ile iş birliği yaparak tilkinin elinden tavşanın çocuklarını kurtarmak için plan yapmaktadır (Resim 4). Nihayetinde tilki bulunmaktadır. Köpekler karadan, eşek arıları da havadan tilkiye saldırırmaktadır. Tilki, aniden gelen saldırı karşısında şaşkına dönmektedir (Resim 5). Köpeklerin ve eşek arılarının sayısı çok kalabalık olduğu için tilki onlara karşı gelememektedir. Nihayetinde çocuklar kurtarılmaktadır. Çocukların kurtulması ile tavşan ailesi huzur içerisinde yaşamlarına devam etmektedir (Resim 6).

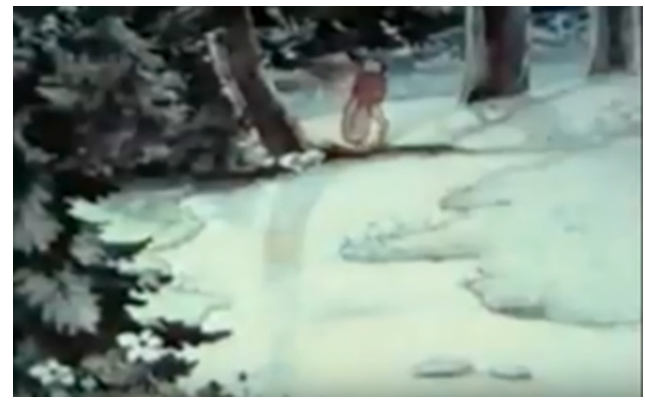

Resim 1

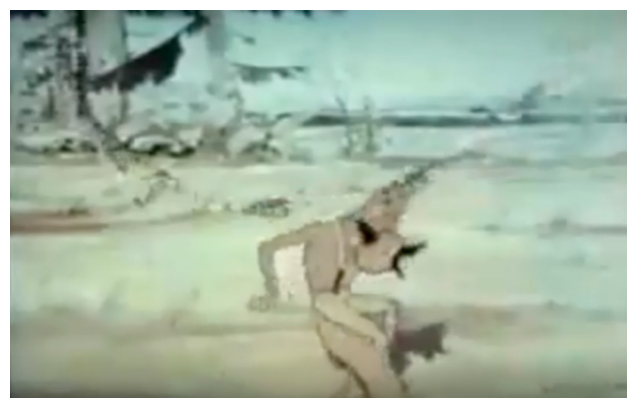

Resim 3

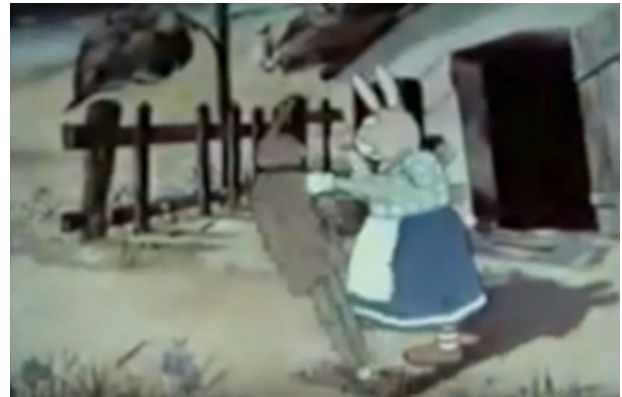

$\operatorname{Resim} 2$

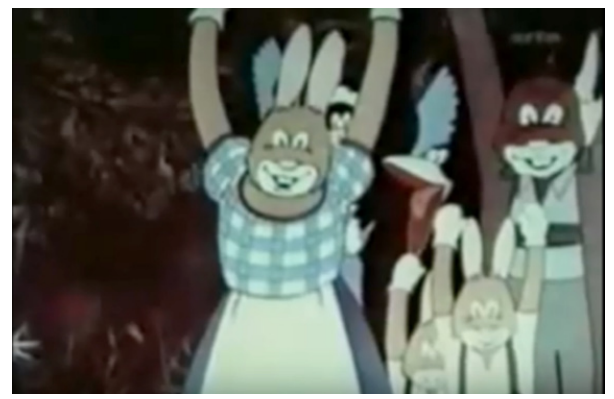

Resim 4 


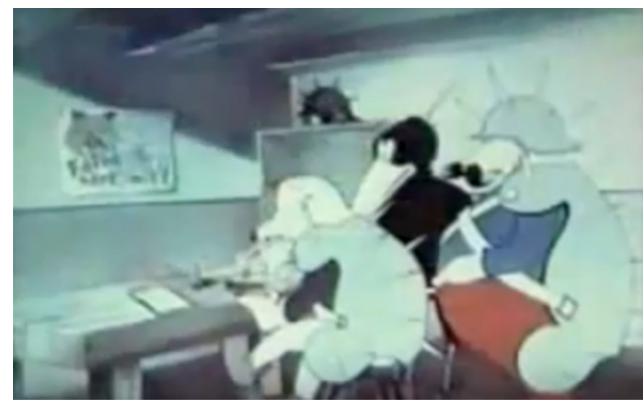

Resim 5

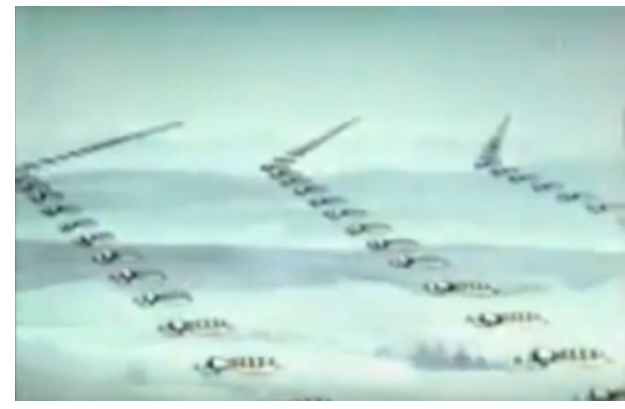

Resim 6

Çizgi filmin yapıldığı 1940 yılında, henüz Nazi Almanyası, Sovyetler Birliği ve ABD ile savaşa girmemişti. Buna karşın Naziler, Avrupa' da şiddetli bir savaşın içinde bulunmaktaydı.

Çizgi filme konu edilen tavşan ailesi, Alman ulusal kıyafetleri giymektedir. Bu aşamada tavşan ailesi, Saussure'ün gösterilen boyutunda, Alman ailesinin temsili olarak yer almaktadır. Tavşanlar çizgi filmde "masumiyet" metaforu olarak kullanılmaktadır. Çizgi filmde çocukları kaçıran tilki Alman halkının düşmanı olarak sunulmaktadır. Tilki, çizgi filmdeki görsel kodlar içerisinde "tehlike", "suç" ve "korku" metaforları olarak yansıtılmaktadır. Çizgi filmde Naziler, tilkiyi doğrudan İngiltere, Fransa veya başka bir düşman ülke olarak sunmaktansa, genel olarak düşmanlığın bir temsili olarak yansıtmayı tercih etmektedir.

Çizgi filmde yer alan köpek görselleri, giydikleri kıyafetlerden Wehrmacht'1 (Alman Ordusu) temsil etmektedir. Baba tavşanın Wehrmacht'tan yardım istemesi ile gösterilen boyutta, Alman halkının Nazi Almanyası'nın ordusuna güvenine vurgu yapılmaktadır. Çizgi filmde Wehrmacht'1 temsil eden köpeklerin doğrudan eşek arıları ile irtibata geçmesi, eşek arılarının uçak sesleri çıkarması, eşek arılarının başlarında Alman pilot şapkalarnın olması, eşek arılarının Luftwaffe'yı (Alman Hava Kuvvetleri) temsil ettiği algısını oluşturmaktadır. Köpeklerin tilkiyi durdurmak için eşek arılarından yardım istemesi, gösterilen boyutta dönemin Alman Hava Kuvvetleri'nin gücünü ön plana çıkarmaktadır. Nitekim Luftwaffe, İkinci Dünya Savaşı'ndan kısa bir süre önce İspanya İç Savaşı'nda milliyetçi güçlere destek vermek amacıyla ülkede büyük bir yıkıma yol açmış ve uluslararası alanda adından sıkça söz ettirmiştir.

Eşek arılarının Luftwaffe' yı, diğer hayvanların da Wehrmacht' 1 temsil ettiği çizgi film içerisinde yer alan sözel kodlardan da anlaşılmaktadır. Eşek arıları, diğer hayvanların da yardımıla tilkiyi bulmakta ve üzerine saldırmaktadır. Tilki, beden dili ve jestleri ile eşek arılarına karşı çaresiz olarak yansıtılmaktadır.

Tilkinin eşek arıları tarafından yenilmesi, gösterilen boyutta Luftwaffe'nın 1940 yılında Avrupa'da elde ettiği hava üstünlüğüne vurgu yapmakta ve Almanya'nın savaşı kazanacağına yönelik de propaganda amaçlı mesaj vermektedir. Tavşan ailesinin çocuklarına kavuştuklarında yaşadığı sevinç, gösterilen boyutta Alman halkının savaşın kazanılmasından sonraki mutluluğu olarak sunulmaktadır. Aynı zamanda tüm hayvanların bir araya gelerek kendilerinden daha güçlü bir hayvanı yenmesi, gösterilen boyutta Alman halkının bir araya gelerek düşmanlarını durdurabileceğine vurgu yapmaktadır.

Tablo 1: Oyunbozan Adlı Çizgi Filmin Göstergebilimsel Analizi 


\begin{tabular}{|l|l|l|}
\hline Gösterge & Gösteren & Gösterilen \\
\hline Hayvan & Tavşan Ailesi & Alman Halkı \\
\hline Hayvan & Eşek Arıları & Luftwaffe (Alman Hava Kuvvetleri) \\
\hline Hayvan & Tilki & Alman Halkının Düşmanı \\
\hline Mekan & Orman & Masumiyet \\
\hline Eylem & $\begin{array}{l}\text { Tavşan Ailesinin Çocuklarının Tilki } \\
\text { Tarafından Kaçırlması }\end{array}$ & $\begin{array}{l}\text { Almanya'nın Düşmanlarının, Alman Halkı } \\
\text { Üzerinde Oluşturduğu Tehlike }\end{array}$ \\
\hline Eylem & $\begin{array}{l}\text { Eşek Arılarının Tilkiye Saldırarak } \\
\text { Çocukları Kurtarması }\end{array}$ & $\begin{array}{l}\text { Luftwaffe'nın Herhangi Bir Tehlike Anında } \\
\text { Ülkesini Savunmaya Hazır Olduğu }\end{array}$ \\
\hline Eylem & Hayvanların İş Birliği & $\begin{array}{l}\text { Mihver Devletleri'nin Bir Araya Gelmesiyle } \\
\text { Birlikte Kendilerinden Daha Güçlü Düşmanı } \\
\text { Yenebileceklerini Ortaya Koymaları }\end{array}$ \\
\hline
\end{tabular}

\section{Doktor ChurkillAdlı Çizgi Filmin Göstergebilimsel Analizi}

Doktor Churkill (Doktor Churkill), Liberio Pensuti yönetmenliğinde İngiltere'ye karşı hazırlanan 1941 yapımı İtalyan propaganda çizgi filmidir. Churkill, İngiltere' de büyük bir bankada yaşayan bir canavardır. Bankada pek çok ulustan alınan paralar bulunmaktadır. Churkill'in yaşadığı yer örümceklerin bulunduğu korkutucu bir yerdir. Bankada ayrıca bir laboratuar dabulunmaktadır. Churkill burada kendisine üzerinde İtalyanca Democrazia (Demokrasi) yazan kimyasal bir karışım hazırlamaktadır (Resim 7). Churkill, oluşturduğu kimyasalı içerek insan haline dönüşmektedir (Resim 8). Churkill, insan haline dönüştükten sonra uçağa binerek, İngiltere' nin dışına çıkmakta ve diğer ülkeleri gezmektedir. Churkill, gezdiği ülkelerin tüm paralarına el koymaktadır (Resim 9). Churkill el koyduğu paraları ellediğinde aniden canavara dönüşmektedir. Bunun için yanına kimyasalı almıştır ve canavara dönüştüğünde kimyasalı içmektedir. Churkill, bir gün yine el koyduğu paraları alıp ülkesine geri dönmek üzereyken üzerinde gamalı haç bulunan bir kol aniden Churkill'in sağ elinden tutmaktadır (Resim 10). Kısa bir süre sonra da üzerinde baltalı çubuklar simgesi bulunan bir diğer kol Churkill'in sol elinden yakalamaktadır (Resim 11). Churkill, bunu üzerine her ikisinden de kaçmaya başlamakta, uçağına binmekte ve İngiltere'ye geri dönmektedir. Churkill'in Londra'ya kaçması üzerine Mihver Devletleri' nin uçakları Londra' yı bombalamaya başlamaktadır. Bombalama sonucunda Londra'da büyük bir yıkım meydana gelmektedir (Resim 12).

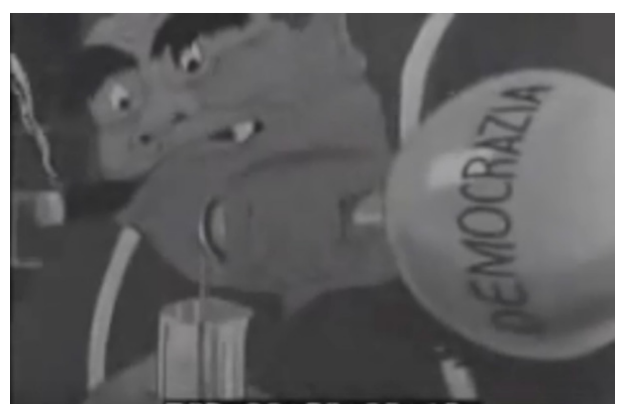

$\operatorname{Resim} 7$

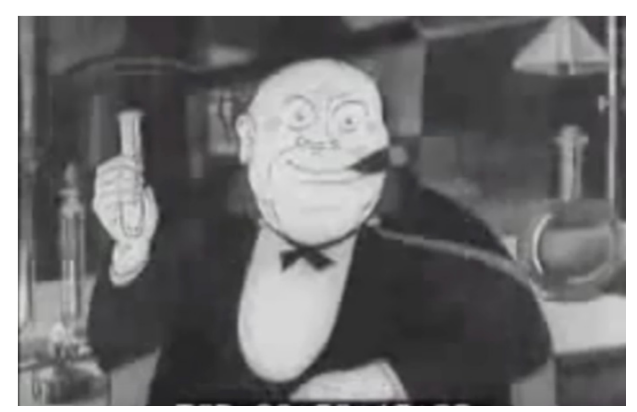

$\operatorname{Resim} 8$ 


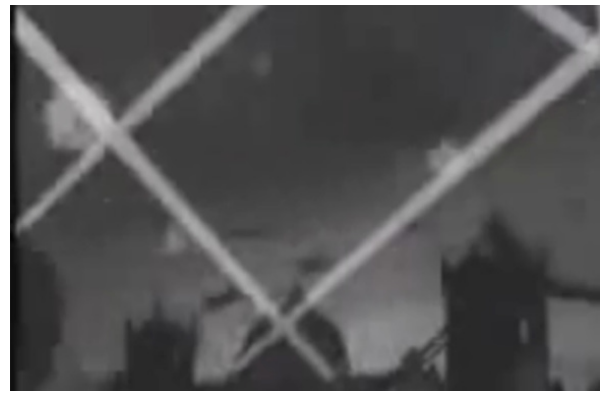

Resim 9

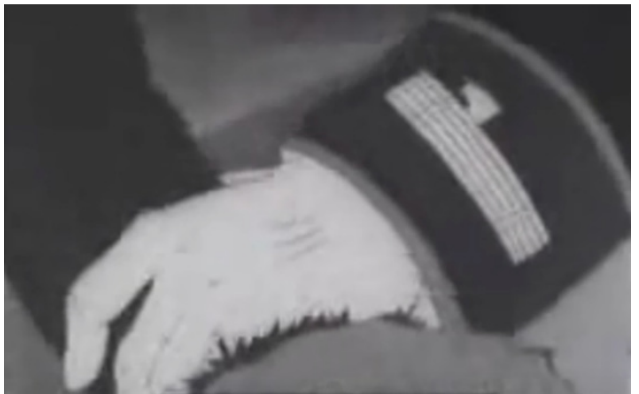

Resim 11

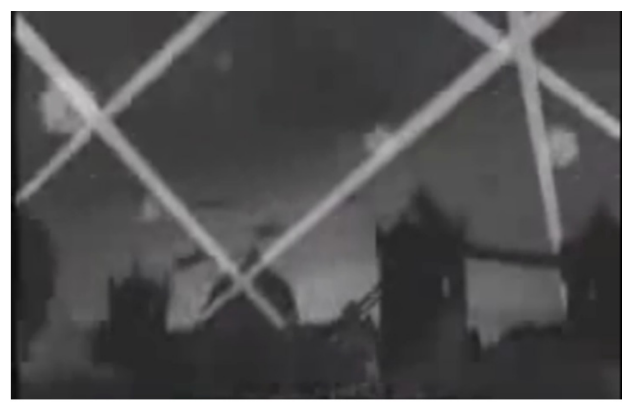

Resim 10

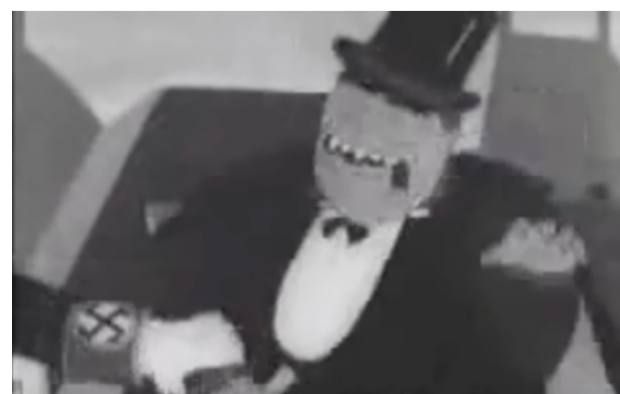

Resim 12

Çizgi filmin yapıldığı 1941 yılında İtalya, İngiltere ile savaş halindeydi. İtalyan propagandasında genel olarak ABD, İngiltere ve Sovyetler Birliği hedef alınmaktaydı. Çizgi filmde, doğrudan İngiltere Başbakanı Winston Churchill üzerinden propaganda faaliyeti yürütülmüştür. Nitekim, çizgi filmin ana karakteri olarak kullanılan Doktor Churkill, gösterilen boyutta Winston Churchill'i temsil etmektedir. Churkill isminin son dört harfi "kill", İngilizce "öldürmek" anlamına geldiğinden, çizgi filmde Churchill'e yönelik olumsuz bir algının oluşması için özellikle kullanılmıştır. Churkill'in normalde insan görünümlü bir canavar olarak yansıtılması, gösterilen boyutta Churchill'in iyi görünümünün altında insanlık için büyük bir tehlike oluşturduğunu ifade etmektedir. Churkill'in ülkeleri gezerek paralarına el koyması, gösterilen boyutta İngiltere'nin sömürgeleri üzerinde kurduğu tahakküme vurgu yapmaktadır. Diğer yandan İngiltere' nin 2. Dünya Savaşı'nda İngiliz Milletler Topluluğu'na ait ulusları savaş için nasıl seferber ettiğini gösterilmektedir. Churkill'in, "demokrasi" adındaki kimyasalı içerek insan haline gelmesi, gösterilen boyutta Churchill'in İngiliz halkına ve dünyaya demokrasi söylemleri ile şirin göründüğüne vurgu yapmaktadır.

Churkill'i durdurmak için ortaya çıkan gamalı haç simgeli kol, gösterilen boyutta Nazi Almanyası'nın metonimi olarak çizgi filmde yer almaktadır. Gamalı haç simgeli kolun Churkill'in elinden tutması, gösterilen boyutta Nazi Almanyası'nın 3 Eylül 1939 tarihinden beri İngiltere ile olan savaşına vurgu yapmaktadır. Kısa bir süre sonra baltalı çubuklar simgeli bir kolun Churkill' in diğer elini tutması da, gösterilen boyutta İtalya' nın Almanya'nın yanında 2. Dünya Savaşı'na dahil olduğu ve İngiltere'ye karşı savaşa girdiğini ifade etmektedir. Churkill'in kurtulmayı başarması, gösterilen boyutta İngiltere' nin 1940 yılının Haziran'ında Dunkerque Tahliyesi'nde Fransa'dan askerlerini tahliyesini anlatmaktadır. Churkill'in öldürmek için Londra' nın bombalanması, gösterilen boyutta Mihver Devletleri' nin İngiltere'ye karşı yürüttükleri hava bombardımanını konu edinmektedir. 
Yapılan hava bombardımanının Churkill'i öldürmek için yapılması, gösterilen açısından Mihver Devletleri'nin İngiltere'ye karşı gerçekleştirdikleri hava bombardımanına haklılık kazandırmak için kurgulanmaktadır. Nitekim, Mihver Devletleri tarafından Londra'ya gerçekleştirilen hava akınlarında yüzlerce İngiliz sivil hayatını kaybetmişti. İtalya yapılan propaganda faaliyeti ile birlikte hava bombardımanlarını meşru bir zemine oturtmayı amaçlamaktadır. Çizgi filmin genelinde; İngiltere' nin dünyayı ekonomik olarak sömürdüğü, 2. Dünya Savaşı'nın çıkmasına yol açtığı, demokrasi adı altında yalnızca kendi çıkarlarına göre hareket ettiğine yönelik propaganda inşa edilmeye çalışıldığı görülmüştür.

Tablo 2: "Doktor Churkill" Adlı Çizgi Filmin Göstergebilimsel Analizi

\begin{tabular}{|l|l|l|}
\hline Gösterge & Gösteren & Gösterilen \\
\hline İnsan & Il Dottor Churkill & İngiltere Başbakanı Winston Churchill \\
\hline Eylem & $\begin{array}{l}\text { Churkill'in Canavar Haline } \\
\text { Gelmesi }\end{array}$ & $\begin{array}{l}\text { Churchill'in 2. Dünya Savaşı'nda Yaşanan } \\
\text { Ölümlerden Sorumlu Tutulması }\end{array}$ \\
\hline Eylem & $\begin{array}{l}\text { Churkill'in yabancı ülkeleri } \\
\text { gezerek altın toplaması }\end{array}$ & $\begin{array}{l}\text { İngiltere'nin diğer ülkeler üzerinde } \\
\text { kurduğu sömürge düzenine vurgu }\end{array}$ \\
\hline Nesne & Demokrasi Şişesi & $\begin{array}{l}\text { Churkill'in İnsanlara İyi Görünmek İçin } \\
\text { Demokrasi Kavramını Sürekli Olarak Öne } \\
\text { Sürmesi }\end{array}$ \\
\hline Simge & Gamalı Haç & Nazi Almanyası \\
\hline Simge & Baltalı Çubuklar & Faşist İtalya \\
\hline Eylem & $\begin{array}{l}\text { Churkill'i Yok Etmek İçin } \\
\text { Londra'nın Bombalanması }\end{array}$ & $\begin{array}{l}\text { İngiltere'ye karşı 2. Dünya Savaşı'nda } \\
\text { Mihver Devletleri'nin Gerçekleştirdiği Hava } \\
\text { Saldırılarını Meşrulaştırmak }\end{array}$ \\
\hline Eylem & $\begin{array}{l}\text { Gamalı Haç ve Baltalı Çubukların } \\
\text { Churkill'i Durdurmak İçin } \\
\text { Kolundan Tutması }\end{array}$ & $\begin{array}{l}\text { Nazi Almanyası ve Faşist İtalya'nın } \\
\text { İngiltere'ye Karş1 2. Dünya Savaş'ndaki } \\
\text { Mücadelesi }\end{array}$ \\
\hline
\end{tabular}

\section{Momotaro'nun Deniz KartallarıAdlı Çizgi Filmin Göstergebilimsel Analizi}

Momotarō no Umizwashi (Momotaro'nun Deniz Kartalları), Mitsuyo Seo yönetmenliğindeki ABD'ye karşı hazırlanan 1943 Japon yapımı propaganda çizgi filmidir. Çizgi film, 1941 yılının Aralık ayında Japon İmparatorluğu tarafından gerçekleştirilen Pearl Harbor Baskını'nı konu edinmektedir. Japon ulusal kıyafetleri içerisindeki Momotaro, tavşan askerleri ile birlikte Pearl Harbor' da bulunan ve çizgi filmde olumsuz bir şekilde yansitılan adaya saldırmaktadır (Resim 13). Saldırı esnasında hayvanlar başlarına Japon İmparatorluk armasını takmaktadır (Resim 14). Adada ABD'ye ait büyük bir donanma bulunmaktadır. Donanmanın başında da ABD'nin bayrağını andıran bir bayrak göndere çekilmiştir (Resim 15). ABD donanmasının başında ise Temel Reis çizgi filminde, Temel Reis'in düssmanı olarak gösterilen Kabasakal bulunmaktadır. Çizgi filmde Kabasakal sarhoş olarak yansıtılmaktadır.Momotaro ve askerleri, ABD donanmasına saldırmasıyla birlikte, Kabasakal ve askerleri savaşmak yerine kaçmaya başlamaktadır (Resim 16). Momotaro ve askerleri ABD donanmasına büyük zarar vermektedir. Kabasakal, savaşın kaybedildiğini anladığı için ABD bayrağını gönderden indirmekte ve onu beyaz bayrak haline getirerek sallamaya başlamaktadır (Resim 17). Kabasakal beyaz bayrağı sallayarak savaşın kaybedildiğini kabul etmektedir. Momotaro ve askerleri savaşın kazanılması üzerine büyük bir sevinç yaşamaktadır (Resim 18). 


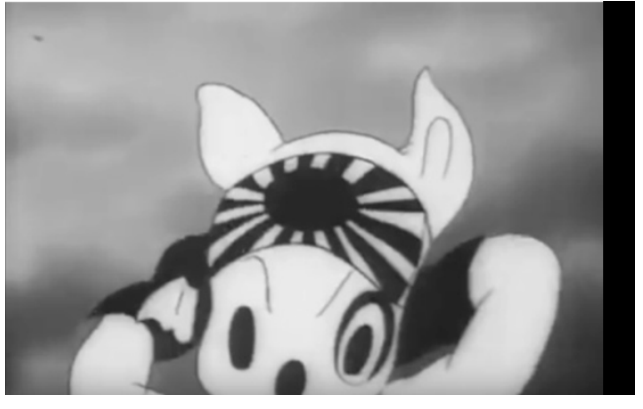

Resim 13

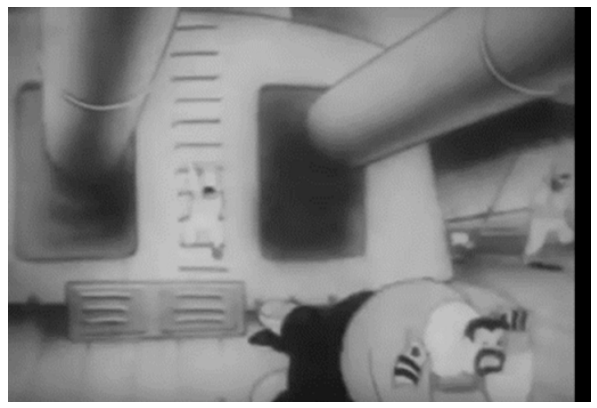

Resim 15

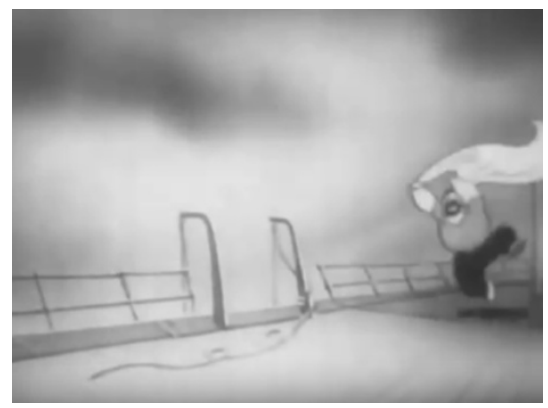

Resim 17

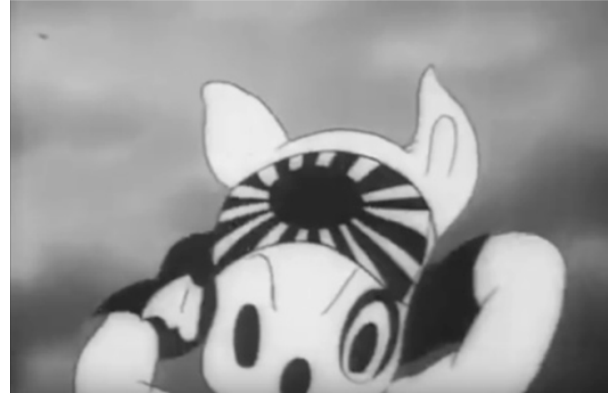

Resim 14

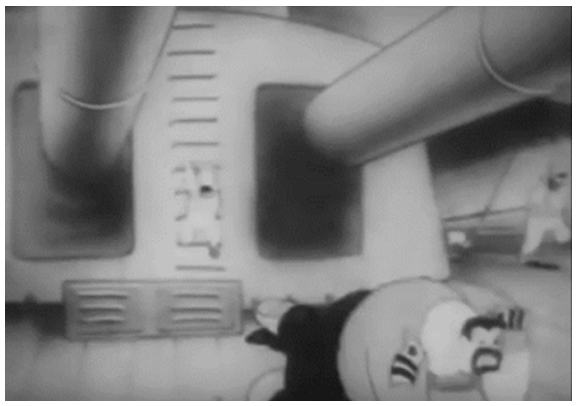

Resim 16

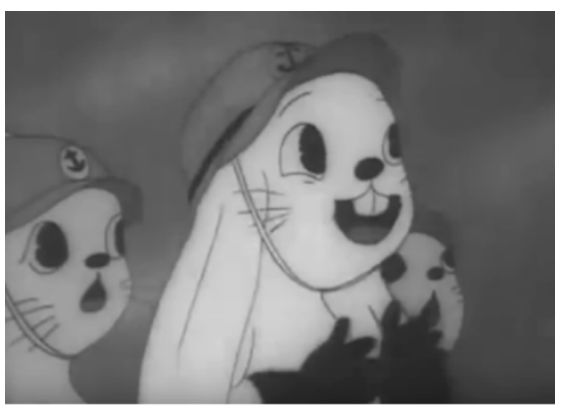

Resim 18

Çizgi film, Japonya' nın ABD’ye yönelik gerçekleştirdiği Pearl Harbor Baskını'ndan iki yıl sonra yayınlanmıştır. Çizgi filmin üretildiği dönemde Japonya, Pasifik'te Müttefik Devletleri ile sıcak çatışma içerisindeydi.

Çizgi filmde görsel kodlar içerisinde, Momotaro'nun Japon İmparatorluğu'na ait asker üniformasından ziyade Japon yerel savaşçı kıyafetlerini giymesi ile, gösterilen boyutta Japonya'nın geçmişteki savaşçı yapısına vurgu yapılmaktadır. Momotaro'nun ve askerlerinin jest ve beden dilleri savaşa yönelik kararlılık ve inançlarını yansıtmaktadır. Çizgi filmde Pearl Harbor'ın olumsuz sunum kodları içerisinde temsil edilmesi, gösterilen boyutta Japonya'nın Pearl Harbor Baskını'nı haklı göstermek amacını taşımaktadır. Çizgi filmde insan karakterinden ziyade Japon askerlerinin tavşan gibi hayvan metonimileri ile temsil edilmesi; gösterilen boyutta savaşın sert ve karanlık yüzünü sevimli göstermek amacını taşımaktadır. Japon askerlerini temsil eden hayvanların başlarına Japon Imparatorluk armasını takmaları, gösterilen boyutta Japon askerlerinin Japon İmparatoru'na içten bir sadakatle bağlı olduklarını göstermektedir. 
Momotaro ve askerlerinin ani bir baskınla saldırıya geçtikleri Pearl Harbor'da ABD donanması komutanı olarak Temel Reis çizgi filmindeki Kabasakal karakterinin kullanılması, gösterilen boyutta ABD askerlerini olumsuz göstermek amacıyla kurgulanmıştır. Nitekim, çizgi filmlerde Kabasakal, doğruluğu temsil eden Temel Reis ile savaşmakta, "kötülük", "düşman" ve "tehlike" gibi olumsuz metaforlar içerisinde sunulmaktadır. Görsel kodlar içerisinde Kabasakal'ın sarhoş olarak sunulması da, gösterilen boyutta ABD askerlerini Japon halkı gözünde itibarsızlaştırmanın bir çabasıdır. Japonların saldırısı sonucu Kabasakal ve askerlerinin savaşmaktan ziyade kaçmaya başlaması, gösterilen boyutta Japon Ordusu'nun aslında güçlü bir düşmanla savaşmadığı imajını vermektedir. Kabasakal'ın teslim olmak için gönderdeki bayrağı indirmesi ve onu silkeleyerek beyaz bayrağa çevirmesi; gösterilen açıdan ABD askerlerinin bayraklarına sayg1 göstermediğine vurgu yapmaktadır. Nitekim, Japon askerler ABD askerleri ile savaşa girerken Japonya bayrağını başlarına bağlayarak savaşmakta ve vatanlarını temsil ettiği için bayrağa saygı göstermektedir. Kabasakal'ın teslim olması, gösterilen boyutta Japonya'nın ABD'ye karşı zaferinin yakın olduğuna işaret etmektedir. Çizgi filmin genelinde; ABD askerlerinin savaşma becerisi olmadığı, savaştan korktukları, Japon askerlerinin ise vatanları için ölmeye hazır oldukları propagandasının inşa edilmeye çalışıldı̆̆ı görülmektedir.

Tablo 3: "Momotaro'nun Deniz Kartallan" Adlı Çizgi Filmin Göstergebilimsel Analizi

\begin{tabular}{|l|l|l|}
\hline Gösterge & Gösteren & Gösterilen \\
\hline İnsan & Genç Momotaro & $\begin{array}{l}\text { Japon İmparatorluk } \\
\text { Donanması'nın Komutanı }\end{array}$ \\
\hline Hayvan & Sevimli Tavşanlar & $\begin{array}{l}\text { Japon İmparatorluk } \\
\text { Donanması'nın Askerleri }\end{array}$ \\
\hline Nesne & $\begin{array}{l}\text { Walt Disney Çizgi Film } \\
\text { Karakteri Kabasakal }\end{array}$ & $\begin{array}{l}\text { Amerika Birleşik Devletleri } \\
\text { Donanması'nın Komutanı }\end{array}$ \\
\hline Eylem & $\begin{array}{l}\text { Hayvanların İmparatorluk } \\
\text { Arması'nı Başlarına } \\
\text { Takması }\end{array}$ & $\begin{array}{l}\text { Askerlerin Japon İmparatorluğu } \\
\text { Adına Savaştığına Yapılan Vurgu }\end{array}$ \\
\hline Eylem & $\begin{array}{l}\text { Momotarove Tavşanların, } \\
\text { Kabasakal ve Adamlarına } \\
\text { Saldırması }\end{array}$ & $\begin{array}{l}\text { 2. Dünya Savaşı'nda Japon } \\
\text { İmparatorluğu'nun ABD ile Olan } \\
\text { Mücadelesi }\end{array}$ \\
\hline Eylem & $\begin{array}{l}\text { Kabasakal ve Askerlerinin } \\
\text { Kaçması }\end{array}$ & Japonya'nın Zaferi \\
\hline Eylem & $\begin{array}{l}\text { Kabasakal'ın Beyaz Bayrak } \\
\text { Sallaması }\end{array}$ & $\begin{array}{l}\text { ABD'nin Eninde Sonunda Savaşı } \\
\text { Kaybedeceğine Yapılan Vurgu }\end{array}$ \\
\hline
\end{tabular}

\section{Sonuç}

Çalışmakapsamında elealınanherüççizgifilmde deMihver Devletleri' ninkamuoylarında etkili olabilmek için Müttefik Devletleri'ne karşı nefret söylemi içerisine girdikleri görülmüştür. Üç çizgi filmde de hava kuvvetlerinin savaşın kazanılmasında önemli bir rol oynadığı üzerinde durulmuştur. Nazi Almanyası'nda propaganda amaçlı üretilen çizgi filmde Sovyetler Birliği, tilki metonimi üzerinden yansıtılmıştır. Tilki "kötülük" ve "tehlike" metaforları olarak çizgi 
filmde sunulmuştur. Buna karşın Naziler, Alman halkını "masumiyet" metaforu olarak sunulan tavşan şeklinde göstererek,Alman halkına yönelik masumiyet oluşturmaya çalışmıştır. Diğer yandan Alman Hava Kuvvetleri de eşek arıları metonimi üzerinden çizgi filmde yansıtılarak, Alman Ordusu'nun daha sevimli hale getirilmesi amaçlanmıştır. Gösterilen boyutta, Sovyetler Birliği'nin Almanya'ya yönelik düşmanca planlara sahip olduğu yansıtılmaya çalışılmıştır. Çizgi filmin genelinde; Sovyetler Birliği'nin Almanya'nın birliği için tehlike oluşturduğu ve bu tehlikenin yalnızca Alman Ordusu tarafından bertaraf edilebileceğine yönelik propaganda mitlerinin inşa edilmeye çalışıldığı görülmüştür.

İtalya, çizgi filmde doğrudan İngiltere Başbakanı Winston Churchill üzerinden İngiltere aleyhine propaganda faaliyeti yürütmüştür. Churchill, Doktor Churkill adında yarı insan yarı canavar bir karakter metonimi üzerinden çizgi filmde yansıtılmıştır. Çizgi filmde, gösterilen boyutta İngiltere'nin demokrasi söylemi ile dünyanın pek çok ülkesini sömürdüğü ve 2 . Dünya Savaşı'nın temel sorumlusu olduğu vurgusu yapılmıştır. Churkill, çizgi filmdeki görsel kodlar içerisinde "sömürü", "tehdit" ve "kötülük" metaforları üzerinden sunulmuştur. Buna karşın gamalı haç ve baltalı çubuk simgeleri ile sunulan Nazi Almanyası ve Faşist İtalya'nın da "kahraman" ve "kurtarıcı" metaforları üzerinden çizgi filmde yansıtıldıkları görülmektedir. Aynı zamanda, Churkill'i yakalamak için çizgi filmde İngiltere'nin bombalanmas1; gösterilen boyutta, Mihver Devletleri'nin Londra üzerinden İngiliz halkını bombalamalarının meşrulaştırma çabası olduğu ortaya çıkarılmıştır.Çizgi filmdeki sunum kodları içerisinde; Mihver Devletleri' nin iş birliği içerisinde meydana gelen hava harekâtları sonucunda İngilizlerin teslim olacağına yönelik propaganda mitinin inşa edilmeye çalışıldığı görülmüştür.

Japonya, çizgi filmde Pearl Harbor Baskını'nı konu edinerek doğrudan ABD'ye yönelik propaganda çalışması yürütmüştür. Çizgi filmdeki görsel kodlar içerisinde Japon askerleri, Nazi Almanyası'nın Oyunbozan adlı çizgi filminde olduğu gibi tavşan metonimileri üzerinden temsil edilerek, "masum" ve "sevimli" gösterilmeye çalışılmıştır. Japon askerleri sunum kodlarında, "kahraman", "vatansever" ve "cesaret" metaforları içerisinde yansıtılmıştır. Buna karşın ABD, Temel Reis çizgi filminde yaptığı kötülükler ile ön plana çıkan Kabasakal metonimi üzerinden temsil edilmiştir. Kabasakal çizgi filmdeki sunum kodlarında "korkaklık", "çaresizlik" ve "güçsüzlük" gibi olumsuz metaforlar üzerinden yansıtılmıştır. Çizgi filmin ana karakteri Momotaro'nun olumsuz sunum kodları içerisinde yansitılan PearlHarbor'a saldırarak Kabasakal ve askerlerini bombalaması; gösterilen boyutta Japonya' nın 1941 yılının Aralık ayında gerçekleştirdikleri Pearl Harbor baskınını meşru gösterme çabası olarak ortaya çımaktadır. Çizgi filmde; Japonların Pearl Harbor'da büyük bir zafer elde ettiğine yönelik propaganda mitinin inşa edilmeye çalışıldığı görülmektedir.

Mihver Devletleri tarafından 2. Dünya Savaşı esnasında çekilen çizgi filmlerde iki temel propaganda amacının olduğu ortaya çıkmaktadır. Birincisi, savaş esnasında alınan kararların (Örneğin, Londra Bombardımanı, Pearl Harbor Baskını) kamuoylarında meşru gösterilmesi; ikincisi ise Müttefik Devletleri'ne yönelik olumsuz algının inşasıdır. Çalışma, 2. Dünya Savaşı'nda Mihver Devletleri tarafından üretilen çizgi filmlerde propagandanın rolünü ortaya koyması bakamından önem taşımaktadır. Buna karşın çalışma, propaganda amaçlı üretilen çizgi filmlerin kitleler üzerindeki etkisini ortaya koyamamaktadır. Bu açıdan gelecek çalışmaların, propaganda amaçlı çekilen çizgi filmlerin insanlar üzerindeki etkisini ortaya koyan saha araştırmalarına yönelmesinin alana katkı sağlayacağı düşünülmektedir. 


\section{Kaynakça} $162-163$

Akarcalı, S. (2003). İkinci Dünya Savaşında İletişim ve Propaganda. Ankara: İmaj Yayınevi.

Çankaya, E. (2008). İktidar Bu Kapağın Altındadır. Gösteri Demokrasisinde Siyasal Reklamcılık. İstanbul: Boyut Yayın Grubu, 32.

Delporte, C. (2001). "Humour as a Strategy in Propaganda Film: the Case of a French Cartoon from 1944". Journal of European Studies, 31(123), 367-377.

Domenach, J. M. (2003). Politika ve Propaganda, Tahsin Yücel, (çev), 2. Basım. İstanbul:Varlık Yayınlar1, 90,80-81. 584.

Eberle, H. ve Uhl, M. (2017). Hitler Kitabı. Mustafa Tüzel, (çev), İstanbul: Alfa Yayınları,

Fiske, J. (2017). İletişim Çalışmalarına Giriş. Süleyman İrvan,(çev), 5. Basım. Ankara:Bilim ve Sanat Yayınları, 127.

Gazi, M. A., Çakı, C., \& Gülada, M. O. (2018). “İkinci Dünya Savaşı'nda Sovyet Kült Lider Propagandasında Vladimir Lenin ve Joseph Stalin'in Sunumu”. Dördüncü Kuvvet Uluslararası Hakemli Dergi, 1(2), 25-42.

Goebbels, J. (2016). Gerçek Yüzüyle Komünizm ve Teori ve Pratikte Bolşevizm. Zehra Köroğlu,(çev), İstanbul: Bilge Karınca Yayınları, 24-25.

Guiraud, P. (2016). Göstergebilim. Mehmet Yalçın, (çev), 3.Baskı. Ankara: İmge Kitabevi, 39.

Held, H. (Yönetmen). (1940). Der Störenfried [Çizgi Film]. Almanya.

Jones, C. C. (1988). Class Tax to Mass Tax: the Role of Propaganda in the Expansion of the Income Tax during World War II. Buff. L. Rev., 37, 685-737.

Jowett, S. G. \& O'donnell, V. (2014). Propaganda \& Persuasion. USA: Sage, 59.

Kalkan Kocabay, H. (2008). Tiyatroda Göstergebilim. İstanbul: E Yayınları, 16.

Kallis, A. (2005). Nazi Propaganda and The Second World War. Germany: Springer, 120

Kuruoğlu, H. (2006). Propaganda ve Özgürlük Aracı Olarak Radyo. Ankara: Nobel Yayın Dağıtım,21.

Loiperdinger, M. (1993). Sieg des Glaubens. Ein gelungenes Experiment nationalsozialistischer Filmpropaganda. In Formative Ästhetik im Nationalsozialismus. Intentionen, Medien und Praxisformen totalitärer ästhetischer Herrschaft und Beherrschung, $35-48$.

Öymen, O. (2014). Bir Propaganda Silahı Olarak Basın. İstanbul: Remzi Kitabevi, 226. 
Patten, F. (1996). Momotaro's Gods-Blessed Sea Warriors: Japan's Unknown Wartime Feature, Animation World, 1(7), 16-18.

Pensuti, L. (Yönetmen). (1941). Il Dottor Churkill, [Çizgi Film]. İtalya.

Raiti, G. C. (2007). “The Disappearance of Disney Animated Propaganda: A Globalization Perspective". Animation, 2(2), 153-169.

Rifat, M. (2013). Açılamalı Göstergebilim Sözlüğü: Kavramlar, Yöntemler, Kuramcılar, Okullar. İstanbul: Türkiye İş Bankası Kültür Yayınları, 99.

Schütz, E. (1995). Das Dritte Reich als Mediendiktatur: Medienpolitik und Modernisierung in Deutschland 1933 bis 1945. Monatshefte, 129-150.

Seo, M. (Yönetmen). (1943). Momotarō no Umiwashi, [Çizgi Film]. Japonya.

Shull, M. S., \& Wilt, D. E. (2014). Doing their Bit: Wartime American Animated Short Films, 1939-1945. The United Kingdom: McFarland, 12.

Sığırcı, İ. (2016). Göstergebilim Uygulamaları, Metinleri, Görselleri ve Olayları Okuma. Ankara: Seçkin Yayıncilık, 31-32.

Tanyeri Mazıcı, E. ve Çakı, C. (2018). “Adolf Hitler'in Korku Çekiciliği Bağlamında Kamu Spotu Reklamlarında Kullanımı”. Erciyes İletişim Dergisi, 5 (3), 290-306.

Tekinalp, Ş. ve Uzun, R. (2013). İletişim Araştırmaları ve Kuramları. 4. Baskı. İstanbul: Derin Yayınları,139.

Winkel, R. V. (2004). Nazi Newsreels in Europe, 1939-1945: the Many Faces of Ufa's Foreign Weekly Newsreel (Auslandstonwoche) versus German's Weekly Newsreel (Deutsche Wochenschau). Historical Journal of Film, Radio and Television, 24(1), 5-34.

Yücel, E. (2017). Propaganda, Hitler'in Müftüsünden Nazi Türklere, Bir Diktatörü Otopsisi. İstanbul: Karakarga Yayınları,156.

Zorlu, Y., Çakı, C., Karaca, M. (2017). Türk Sinemasında Nazizm İdeolojisi:“Kırımlı" Filmi ve Göstergebilimsel Analizi, Sosyoloji Konferansları - Istanbul Journal of Sociological Studies No: 56 (2017-2) / 65-93. 